INTERNATIONAL HIGHER EDUCATION, Number 62 Winter 2011

Pages 11-14

Agents and Third-Party Recruiters in International Higher Education

Philip G. Altbach

Philip G. Altbach is the Monan University Professor and director of the Center for International Higher Education at Boston College. E-mail: altbach@bc.edu.

A specter is now haunting international higher education-the dramatic proliferation of third-party recruiters and agents. Their job is to recruit prospective students in countries that send large numbers of students abroad to study at specific institutions as well as to provide general information about studying abroad. Many officials are authorized by academic institutions in the receiving countries-specifically in the United States, Britain, and Australia-to offer admission to students and facilitate their enrollment.

While by no means a new trend, this phenomenon is growing in size, scope, and notoriety, as international enrollments have become a compelling part of some universities' bottom lines. The operators, of course, do not work without any source of income. They are paid by the universities that utilize them, usually by providing a fee, based on how many students are enrolled. Sometimes, shockingly, they are also paid by prospective students. 
This article has a simple argument that agents and recruiters are impairing academic standards and integrity and should be eliminated or severely curtailed. Providing information to prospective students is fine, but money should not change hands during the admissions process, and universities should not hand the power to admit-after all, a key academic responsibility-to agents or entities overseas.

\section{Old Ways AND A New WAVE}

Thirty years ago, most students interested in studying abroad would locate information, apply to his or her preferred institutions, and enroll. In the days prior to the Internet, information could be obtained directly by writing to overseas universities or in some cases by going to libraries sponsored by embassies and information centers in major cities in the developing world supported by the main host countries-the Soviet Union, Britain, France, and the United States. Internationally mobile students were relatively few in number. In 1981, there were 912,300 internationally mobile students. The total has grown by three times in the past 30 years. Many students came from relatively sophisticated families able to access information and make informed choices or were sponsored by governments or other agencies. Universities in host countries seldom placed internationalization at the top of their agendas, and few, if any, looked to make money from overseas students. Cold War politics and neocolonial ties stimulated the major powers to sponsor information centers overseas.

This environment has changed. Indeed, practices only a few decades old seem quaint in today's globalized world, where higher education is big business 
for many and perhaps 3 million students study abroad-the large majority coming from Asia and going to the main English-speaking Western countries and Australia. The United States hosted 671,000 of these foreign students—or 21 percent of the global total. These students contributed more than $\$ 17.65$ billion to the US economy and many billions more to the other main host countries.

The key shifts include the rise of the Internet, the commercialization of international study, the transformation of study abroad from an elite to a mass phenomenon. While formerly limited mainly to an elite few, participating students were often provided with scholarships from home or host countries. International study is now a mass phenomenon where funding comes overwhelmingly from individual overseas students or their families, and the students themselves come from much wider social-class backgrounds and from many more countries than was the case in the past.

The Internet permits easy access to information concerning higher education institutions everywhere, although even a cursory glance at the Web sites of many universities reveals a striking lack of transparency that even borders on false advertising. Even degree mills can be designed to look like Oxford-sometimes even stealing pictures of Oxford. But good information is available to individuals who have the ability to carefully separate fact from fiction-not an easy task.

The Cold War ended by 1990, and most host countries have eliminated or cut back their overseas information centers. Some, like Australia, have purposely commercialized international student recruiting. The Australian government established the IDP agency to build higher education as an export industry. 
Other countries, including the United Kingdom, have moved to commercialize international higher education.

At the same time, the United States has repeatedly cut the budgets for overseas libraries and information centers without thinking about the consequences and now faces the costly investment of reopening centers and libraries and rebranding and remarketing one of America's most valuable "exports."

As the number of overseas students has grown, the level of sophistication of the applicants has declined. At one time, fewer applicants were in large part interested in top universities overseas, although some government-sponsored programs placed students in less prestigious institutions. However, many of today's potential students have little knowledge about higher education prospects and may want to study abroad because they cannot find access at home. Moreover, they feel that somehow an overseas qualification will boost their job prospects or serve as a prelude to migration abroad.

Many more academic institutions have entered the competition for international students. Most of these new entrants are not top "name-brand" universities but are rather lesser-known—and sometimes lower-quality—schools of all kinds. These schools turn to recruiters since they feel that they have no alternative way to attract students from other countries. It is surprising that some quite respectable American universities have turned to agents and recruitersperhaps feeling insufficient confidence that their quality and brand could attract overseas students. Top-ranked universities remain preferred destinations for the best and brightest students, but they can accommodate only a tiny minority of those who apply. 


\section{Agents AND ReCruiters ENTER}

This new environment produced an information and access vacuum that needed to be filled. Unfortunately, this deficiency has been accommodated in the worst possible way. Many universities, especially those with no international profile, seeking to attract international students find that they cannot easily obtain access to the potential market. Students find it difficult to locate reliable information about possible places to study amidst the thicket of competing Web sites and the myriad of advertisements that one can find in newspapers, train stations, and elsewhere in the developing world. The Internet has not solved the problem in part because it does not distinguish quality and provides unevaluated and unfiltered information. There is no way to easily evaluate the quality or veracity of information. Agents and recruiters have stepped into this environment of information overload and claim to provide a roadmap to the plethora of "information" currently available on the Internet and elsewhere.

\section{The Actual Practices}

If agents and recruiters only provided information, today's situation would not amount to a crisis. It would simply be problematical because the evaluation of the information would still be questionable. They are, of course, hired chiefly by potential host universities and other higher education providers to attract students to their institutions. Not information providers, the agents are salespeople. Their purpose is to sell a product, and they can use any required methods. They do not present alternatives or provide objective guidance to the potential applicants. Many of these operators-although it is not known how 
many—have authorization to actually admit students, often based on murky qualifications. Some of the least-scrupulous agents accept payment from both sides-their employing school or schools in the host country, as well as from the applicants-a clear violation of ethical standards. Most agents and recruiters are independent operators who have contracts with one, or more, overseas institution. The universities in the host countries that employ these personnel typically are the less-prestigious schools with little visibility overseas and often a tremendous financial need for foreign students to balance their own "bottom lines."

American federal law forbids payments to recruit domestic students. Thus, one wonders why it is appropriate, or even legal, for a university to pay agents to "import" international students whereas not domestic students.

Agents and recruiters have no stated qualifications, nor are they vetted by anyone. Efforts are now underway to create "standards" for this new "profession" but with no powers to either measure compliance or discipline violators. Organizations like NAFSA: Association of International Educators, the largest membership organization of international education professionals, accept these operators as members with no questions asked, thus giving an aura of respectability to them. Other groups, such as the American Association of Collegiate Registrars and Admissions Officers, have raised serious inquiries about their role. Current efforts to set standards and somehow "legitimize" agents and recruiters through a new organization called the American International Recruitment Council may be seen as too closely linked to them. 


\section{THE SOLUTION}

The solution to this growing phenomenon is simple: abolish them. Agents and recruiters have no legitimate role in international higher education. They are unnecessary and often less than honest practitioners who stand in the way of a good flow of information to prospective students and required data about these students to academic institutions in the host countries.

Objective and accurate information and guidance are needed for both institutions and students. These sources can be provided through the Internet, preferably through Web sites with some "seal of approval" from a group of respected universities or an international or regional organization that has universal credibility. It would be helpful if countries that eliminated or cut back on information centers and libraries overseas could restore them. The cost is not high and the yield in goodwill, and reliable data would be immense. A significant role may exist for independent consultants who provide information and prepare students for the application process overseas but have no links and receive no money from the universities. Actually, a new organization, the Association of International Graduate Admissions Consultants, has been founded to establish and enforce appropriate standards relevant to this new role.

Universities in the host countries should immediately cease using agents and recruiters. Better and more useful information should be provided by universities themselves to more effectively inform prospective applicants. This goal may include visits by university admissions staff to potential students overseas for the purpose of information sharing.

The stain of commercialization in international higher education has been tremendously aided by agents and recruiters. It is high time that these operators 
are eliminated and replaced with open and transparent ways of providing information to prospective students. The admissions process should be put back where it belongs-students applying for study and colleges and universities choosing those best qualified-based on reliable individually submitted applications. 